\title{
Features, recent application and conditions for the correct use of seismic isolation systems
}

\author{
A. Martelli ${ }^{1}$, M. Forni ${ }^{2}$ \& G. Panza ${ }^{3}$ \\ ${ }^{I}$ Faculty of Architecture, University of Ferrara, Italy \\ ${ }^{2}$ Technical Unit on Seismic Engineering, ENEA, Italy \\ ${ }^{3}$ Department of Geosciences, University of Trieste, Italy
}

\begin{abstract}
Over 16,000 structures have been protected in the world by seismic isolation (SI) and other anti-seismic systems. Such structures are located mostly in Japan, but they are more or less numerous in more than 30 other countries, including Italy (which is now fourth at worldwide level for the number of isolated buildings, after Japan, China and the Russian Federation). Application of SI is increasing everywhere, although its extent is strongly influenced by earthquake lessons and the features of the design rules used. It concerns both new and existing structures of all kinds. This paper provides a short overview on its recent progress worldwide and on the behaviour of seismically isolated buildings during recent earthquakes, based on the most recent information available to the authors (including some preliminary data on the effects of the 2011 Christchurch and Tohoku events). Particular attention is paid to the isolated buildings in Italy, in the context of the effects of recent quakes (2002 Molise and Puglia and 2009 Abruzzo events). Based on the Italian experience, some important conditions for the correct use of the anti-seismic systems are also stressed in the Conclusions. Keywords: anti-seismic systems; seismic isolation; energy dissipation; seismic input; new constructions; retrofits; seismic codes.
\end{abstract}

\section{Introduction}

Over 16,000 structures in the world have been protected by anti-seismic (AS) techniques, mainly by seismic isolation (SI) or energy dissipation (ED) [1-7]. They are located in more than 30 countries (fig. 1) and concern both new constructions and retrofits of existing structures of all kinds: bridges and 

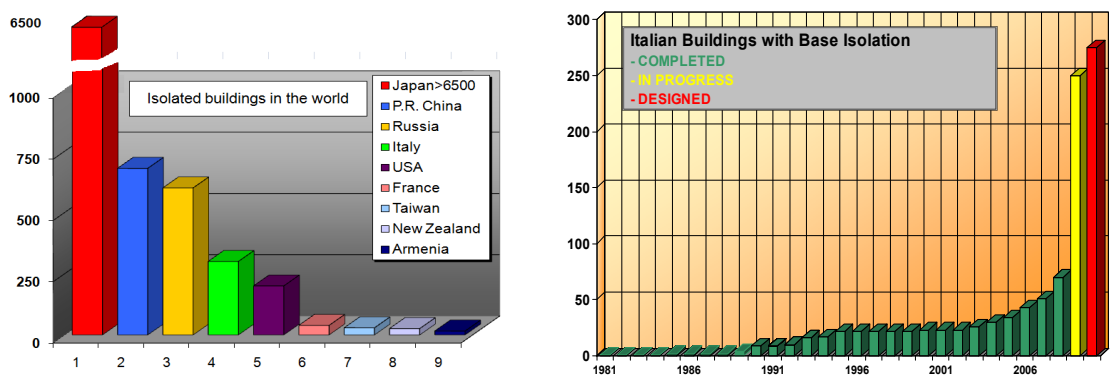

Figure 1: Overall numbers of buildings with SI in the most active countries (left) and in Italy during years (right).

viaducts, civil and industrial buildings, cultural heritage and industrial components and installations, including some high risk nuclear and chemical plants.

The use of the AS systems in a civil context already includes not only the strategic structures (civil defence centres, hospitals) and the public ones (schools, churches, commercial centres, hotels, airports), but also residential buildings and even many small and light private houses. Everywhere, the number of such applications is increasing, although it is strongly influenced by earthquake lessons and the availability and features of the design rules used.

Most SI systems rely on the use of rubber bearings (RBs), namely High Damping Rubber Bearings (HDRBs), or Lead Rubber Bearings (LRBs) or (mainly in Japan) Low Damping Rubber Bearings (LDRBs) in parallel with dampers; in buildings, some plane surfaces steel-Teflon (PTFE) Sliding Devices (SDs) are frequently added to the RBs to support their light parts and (if they are significantly asymmetric in the horizontal plane) to minimize the torsion effects.

\section{Application in Japan}

Japan, thanks to the availability of an adequate specific code since 2000 and the free adoption of SI since 2001, is consolidating its worldwide leadership on the use of the AS systems and devices. In fact, at the end of 2009, over 5,000 Japanese buildings or houses had already been protected by SI (fig. 1) and about 3,000 more had been provided with ED systems [3] (according to recent information, the Japanese isolated buildings are now about 6,000 [8]).

Japan, where the first application of base SI dates back to 1985, is continuing the extensive adoption of the AS systems initiated after the excellent behaviour of two isolated buildings near Kobe during the 1995 Hyogo-ken Nanbu quake, of magnitude $\mathrm{M}=7.3[3,7]$. At least until the extremely violent Tohoku quake and tsunami of March 11, $2011(\mathrm{M}=9.0)$, this behaviour was confirmed for all Japanese buildings protected by SI during all severe events which followed that of 1995, namely those of Tokachi Offshore $(\mathrm{M}=8.0,2003)$, Niigata Chuetsu $(\mathrm{M}=6.8,2004)$, Fukuoka West Offshore ( $\mathrm{M}=7.0,2005)$, Niigata Chuetsu Offshore $(\mathrm{M}=6.8,2007)$ and Iwate-Miyagi Inland $(\mathrm{M}=7.2,2008)$ [8]. Japanese, on the one hand, have confirmed the trend of their country, initiated 
some years ago, to isolate even high-rise buildings and sets of buildings supported by a common isolated reinforced concrete (r.c.) structure (the so called "artificial ground", a solution which enables large savings of construction costs) and, on the other hand, are more and more using SI to protect even very small and light private houses $[3,4,7]$.

Based on recent data [8], the Japanese isolated high-rise buildings are rather numerous and include 250 condominiums, while the isolated houses are already about 3,500 (they were about 3,000 at the end of 2009 [3]). More generally, 46\% $(1,100)$ of the Japanese isolated large buildings (e.g. excluding houses) are condominiums, $20 \%$ offices, $12 \%$ hospitals and $2 \%$ schools; most of these large buildings are new constructions (the retrofits of the existing ones are 90).

About 1,000 Japanese buildings (including several high-rise ones) and 2,000 private houses had also been protected by various kinds of dampers at the end of $2009[3,4,7]$. The use of the AS systems also recently increased in Japan for the protection of cultural heritage and for that of bridges and viaducts $[3,4,7]$. For the latter it began rather later than for buildings; it is largely based on the use of HDRBs and LRBs and considerably extended especially after the 1995 Hygo-ken Nanbu earthquake (by becoming obligatory for overpasses in Kobe).

As to the industrial plants, besides performing detailed studies for the SI (even with three-dimensional - 3D - systems) of various kinds of future nuclear reactors, Japanese erected the Nuclear Fuel Related Facility on 32 LDRBs and LRBs at the beginning of the 2000s [3, 4, 7]. In 2006, they also began the application of SI to large industrial factories: the first, concerning the fabrication of semi-conductors, was built on LRBs and Viscous Dampers (VDs). At least two further similar factories were already in use at the end of 2009 [3, 4, 7].

With regard to the Tohoku (or Sendai) earthquake, it is noted that the related seismic hazard was considerably underestimated, as for several previous violent events all over the world (table 1) [9]. Moreover, the main event of March 11, 2011 (which took place at 2:46 p.m. local time) was followed by a very large number of secondary shocks: on March 28 they had already been 3 of $M>7.0$ (during the same afternoon), 44 of $\mathrm{M}>6.0$ and 180 of $\mathrm{M}>5.0$ [10]. Furthermore, on April 7 a new earthquake of $M>7.0$ took place, with epicentre at $66 \mathrm{~km}$ from Sendai, which, besides causing 3 casualties and 140 wounded persons and the temporary interruption of electric energy distribution, damaged the Onagawa nuclear installation (where its 3 Boiling Water Reactors, BWRs, had not shown any damage during the event of March 11).

The dynamic behaviour of the Japanese isolated buildings during the Tohuku earthquake and its aftershocks was not yet exactly known to the authors of this paper at the time at which they wrote it (April 2011), due to the understandable confusion still reigning in Japan and other priorities of the local experts.

Thus, the authors of this paper had only some general information on this topic, received from Dr. Nagahide Kani, Director of the Japan Society of Seismic Isolation (JSSI) [10], only a few days prior to the event of April 7 (similar to the Italian association GLIS - Isolation and Other Anti-Seismic Design Strategies, 
Table 1: List of the top eleven deadliest earthquakes occurred during the period 2000-2011, and the corresponding intensity differences $(\Delta \mathrm{I})$ among the observed values and those predicted by the Global Seismic Hazard Assessment Program, or GSHAP $(\Delta \mathrm{I}$ is computed from the observed magnitude $M$ and the maximum Peak Ground Acceleration (PGA) values given by GSHAP around the observed epicentre, respectively, using existing relationships [9]; Roman numerals give the difference in natural values of macroseismic intensity; for 9 out of 11 events the GSHAP values severely underestimate the observed ones).

\begin{tabular}{|c|c|c|c|c|}
\hline $\begin{array}{l}\text { Earthquake name } \\
\text { and location }\end{array}$ & Date & $\begin{array}{l}\text { Magnitude } \\
\text { (M) }\end{array}$ & $\begin{array}{l}\text { Intensity } \\
\text { difference } \\
\quad(\Delta \mathrm{I})\end{array}$ & Casualties \\
\hline $\begin{array}{l}\text { Tohuku or Sendai } \\
\text { (Japan) }\end{array}$ & $\begin{array}{l}\text { March 11, } \\
2011\end{array}$ & 9.0 & III & $>20,000 ? ?$ \\
\hline $\begin{array}{l}\text { Port-au-Prince } \\
\text { (Haiti) }\end{array}$ & $\begin{array}{c}\text { January } 12, \\
2010\end{array}$ & 7.3 & II & 222,570 \\
\hline $\begin{array}{c}\text { Padang (Southern } \\
\text { Sumatra, } \\
\text { Indonesia) }\end{array}$ & $\begin{array}{l}\text { September } \\
30,2009\end{array}$ & 7.5 & II & 1,117 \\
\hline $\begin{array}{c}\text { Wenchuan } \\
\text { (Sichuan, P.R. } \\
\text { China) }\end{array}$ & $\begin{array}{l}\text { May } 12, \\
2008\end{array}$ & 8.1 & III & 87,587 \\
\hline $\begin{array}{l}\text { Yogyakarta (Java, } \\
\text { Indonesia) }\end{array}$ & $\begin{array}{l}\text { May 26, } \\
2006\end{array}$ & 6.3 & $=$ & 5.749 \\
\hline $\begin{array}{c}\text { Kashmir (Northern } \\
\text { India - Pakistan } \\
\text { border region) }\end{array}$ & $\begin{array}{l}\text { October } 08, \\
2005\end{array}$ & 7.7 & II & 86,000 \\
\hline $\begin{array}{l}\text { Nias (Sumatra, } \\
\text { Indonesia) }\end{array}$ & $\begin{array}{l}\text { March 28, } \\
2005\end{array}$ & 8.6 & III & 1,313 \\
\hline $\begin{array}{l}\text { Sumatra-Andaman } \\
\text { (Indian Ocean) }\end{array}$ & $\begin{array}{l}\text { December } \\
26,2004\end{array}$ & 9.0 & IV & 227,898 \\
\hline Bam (Iran) & $\begin{array}{l}\text { December } \\
26,2003\end{array}$ & 6.6 & $=$ & 31,000 \\
\hline $\begin{array}{l}\text { Boumerdes } \\
\text { (Algeria) }\end{array}$ & $\begin{array}{c}\text { May 21, } \\
2003\end{array}$ & 6.8 & II & 2,266 \\
\hline $\begin{array}{l}\text { Bhuj (Gujarat, } \\
\text { India) }\end{array}$ & $\begin{array}{c}\text { January } 26, \\
2001\end{array}$ & 8.0 & III & 20,085 \\
\hline
\end{tabular}


JSSI is a corporate member of the Anti-Seismic Systems International Society $A S S I S i)$. In particular, on April 4, Dr. Kani wrote them that:

- in the Tohoku area there are about 130 seismically isolated buildings, most of which behaved well, at least without considering the tsunami effects;

- several isolated buildings are located in the area hit by the tsunami and JSSI was checking their integrity, but no information was available yet;

- in the Tokyo area (450 km from the epicentre), where long period and long duration seismic vibrations were felt, the isolated buildings behaved well;

- in the Kobe and Osaka areas (850 km from epicentre) few of the isolated buildings were slowly shifted for a long time (approximately 15 to 20 minutes) by long period and long duration vibrations, due to low damping of the dampers installed in these buildings (this behaviour was different for the different buildings, depending on the kind of dampers installed inside them);

- at Fukushima an isolated building located at the site of the nuclear power plants was already extremely useful and was considered as tentative headquarters for the emergency activities of TEPCO (the company owning the plants), compatibly with the level of the radiations present in the site.

Some information concerning the isolated bridges and viaducts was also provided, by Prof. Kazuhiko Kawashima of Tokyo Institute of Technology, some days later [11]. He showed that, contrary to the steel bearings, the RBs which have been installed on this structure kind since 1990s (LRBs and HDRBs) mitigated damage. However, several RBs failed at two locations of the East Sendai Expressway (for reasons to be clarified). He also showed that a number of bridges was damaged by the tsunami. Damage was possibly developed by deck rotation toward the upstream side, resulted from the uplifting force. Japanese believe that, if failure of bearings (particularly downstream side bearings) due to the uplifting force can be prevented, damage of the tsunami may be mitigated. Thus, it has been recommended to install "unseating prevention devices for tsunami", by considering that restrainers which are widely used for unseating prevention devices for quakes may be effective if set in the vertical direction.

\section{Application in the P.R. China}

In the Peoples' Republic (P.R.) of China very ancient monasteries, temples and bridges, protected by means of rough sliding SI systems, are still standing, which withstood numerous earthquakes, including very violent events, up to $M=8.2$ $[1,7]$; however, the application of modern SI systems began only in 1991. In any case, initially the SI systems, then the ED devices too have rapidly got a footing since that year $[1,3,4,7]$.

In October 2008, the number of isolated Chinese buildings was about 650 [7]. In November 2009 a further significant extension of the applications of SI and the other AS device kinds in China was reported; in particular, the number of the newly erected isolated buildings per year doubled there after the $\mathrm{M}=8,1$ Wenchuan earthquake of May 12, 2008, by increasing from 50 to 100 per year $[3,4]$. This more rapid increase of the number of building applications of SI was due to both the excellent behaviour of two r.c. isolated buildings and even a 
6-storey masonry one during the aforesaid earthquake (although, as shown by table 1 , its violence had been largely underestimated, by a factor close to 10 for the peak ground acceleration, PGA) and the fact that the Chinese code (which still requires the submission of the projects the isolated buildings to the approval of a special commission) permits to reduce the seismic loads acting on the superstructure and, consequently, the foundations of such buildings $[3,7]$.

In November 2009 SI systems had been installed in the P.R. China in 32 bridges and 690 buildings, while 83 buildings had been protected by ED devices, 16 by Tuned Mass Dampers (TMDs) and 5 by semi-active or hybrid systems [3, 4]. The latter had also been installed in 8 bridges. Several building applications of SI are to dwelling buildings, even new masonry constructions. SI is also applied to rather tall buildings (to 19 storeys) and not only at the building base or at the top of the lowest floor, but also on more elevated floors (for risings or for erecting highly vertically asymmetric constructions), or at the building top (to sustain, in the case of retrofit, one or more new floors acting as a TMD), or also on structures that join adjacent buildings having different vibrational behaviours. Chinese applications of SI also include sets of buildings on "artificial grounds", base and roof SI of stadiums, isolation from both seismic and traffic vibrations (by means of 3D devices), as well as the protection of valuable objects (e.g. electronic equipment and art objects) by means of SI tables and that large chemical components, like new Liquefied Natural Gas (LNG) tanks [3, 4, 7].

\section{Application in the Russian Federation}

The Russian Federation is now third for the number of isolated buildings, with over 600 applications at the end of 2009 [3, 4]. The use of modern SI systems, formed by RBs, frequently in conjunction with SDs and/or dampers (similar to those adopted in the other countries), is going on replacing that of the previous so called "low cost" isolators (reversed mushroom-shaped r.c. elements), which had been installed since the years 1970s. After the retrofits of some important historical buildings [1, 6], recent Russian application includes even high-rise buildings, in particular in Sochi [3, 4, 7]. For some of these Italian isolators have been used (e.g. for the new r.c. 27 storeys Sea Plaza Hotel, which is protected by 102 Italian HDRBs [3, 4]).

\section{Application in the USA}

The USA are still at the second place, after Japan, for the overall number of applications of the AS systems and devices [3, 4]. In this country, however, such applications are satisfactorily progressing only for bridges and viaducts and for buildings protected by ED systems [3, 7]. They concern both new constructions and retrofits. More precisely, HDRBs, LRBs and, more recently ED devices and Shock Transmitter Units (STUs) have already been installed in about 1,000 U.S. bridges and viaducts, located in all U.S. states [3], while dampers of various types already protect over 1,000 buildings $[1,3]$. 
On the contrary, as far as SI of buildings is concerned, the number of new applications remains still limited (recently 3 or 4 per year), in spite of the excellent behaviour of some important U.S. isolated buildings during the 1994 Northridge earthquake [1,6], and the long experience of application of this technique to such structures (since 1985). This is a consequence of the very penalizing design code in force in the USA for the isolated buildings: according to recent information, the US seismically isolated buildings remain now "only" $100 \div 200$, although they are mostly very important and half of them are retrofits, even of monumental buildings $[3,4,7]$.

SI of US buildings has been performed using HDRBs, LRBs (in some cases in conjunction with LDRBs, SDs, VDs and other ED devices), as well as, more recently, the Friction Pendulum System (FPS), which was the first kind of Curved Surface Sliders (CSSs) to be developed. As to the design earthquake levels adopted in California, we note that they correspond to very large magnitudes $\mathrm{M}$ (e.g. $\mathrm{M}=8.3$ for the new 911 Emergency Communications Centre erected in San Francisco in the years 1990s and M =8.0 for the San Francisco City Hall retrofitted with 530 LRBs in 2000 [3, 4, 7]): this imposes the adoption of SI (as the only possibility) for these applications, in spite of its large cost in the USA.

\section{Application in Italy}

Fifth and first in the Western Europe for the overall number of applications of the AS devices remains Italy (fig. 1) [1, 3, 4, 7]. There the use of the AS systems began in 1975 for bridges and viaducts and in 1981 (namely 4 years before Japan and the USA), for buildings [7], but, later, it was rather limited several years long (due to the lack of design rules to the end of 1998, then to their inadequacy and very complicated and time-consuming approval process to May 2003) [1].

Significant application has restarted in Italy for some years, initially as a consequence of the collapse of the Francesco Jovine primary school in San Giuliano di Puglia (Campobasso) during the 2002 Molise and Puglia quake and the subsequent enforcement of the new Italian seismic code (May 2003), which freed and simplified the adoption of the AS systems [3, 7]. However, the use of SI became particularly rapid especially after the Abruzzo earthquake of April 6, $2009(\mathrm{M}=6.3)$, as a consequence of the damage caused by this event to the conventionally founded structures and cultural heritage [3, 4]. Thus, in 2009, Italy overtook the USA for the number of isolated buildings and industrial structures and components: those in use were about 70 before the Abruzzo earthquake, with further $20 \div 30$ under construction or design (see, for instance, figs. 2-5), while they are now approximately 300 and several further applications to new-built and retrofitted structures of these kinds are in progress. 

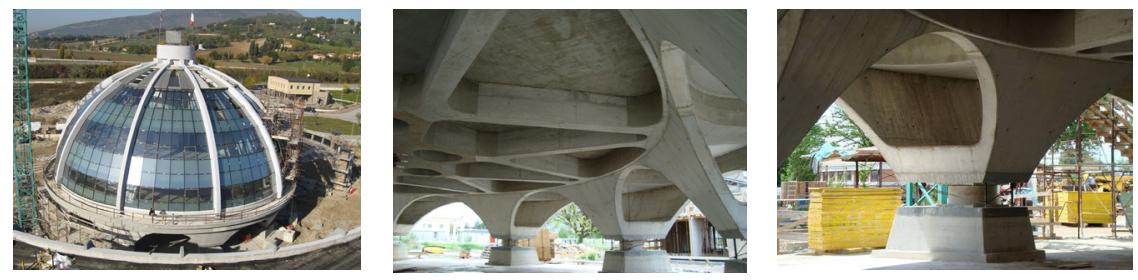

Figure 2: $\quad$ The main building, erected on 10 HDRBs of $1 \mathrm{~m}$ diameter (shown at the centre and on the right, covered by provisional protections) and the adjacent service building, isolated by means of HDRBs and SDs, of the Emergency and Management Operative Centre of the new Civil Defence Centre of Central Italy in Foligno, near Perugia (their construction was completed in 2010 and its safety was certified by A. Martelli in February $2011[3,4,7])$.
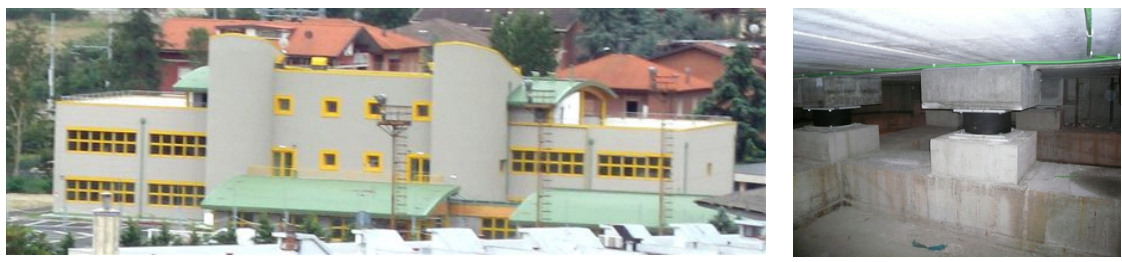

Figure 3: The new school of Marzabotto (Bologna, seismic zone 3), which was isolated (with the collaboration of ENEA) by means of 28 HDRBs and 14 SDs, with $500 \mathrm{~mm}$ diameters (it is the first isolated school in Northern Italy; its safety was certified by A. Martelli in September 2010).
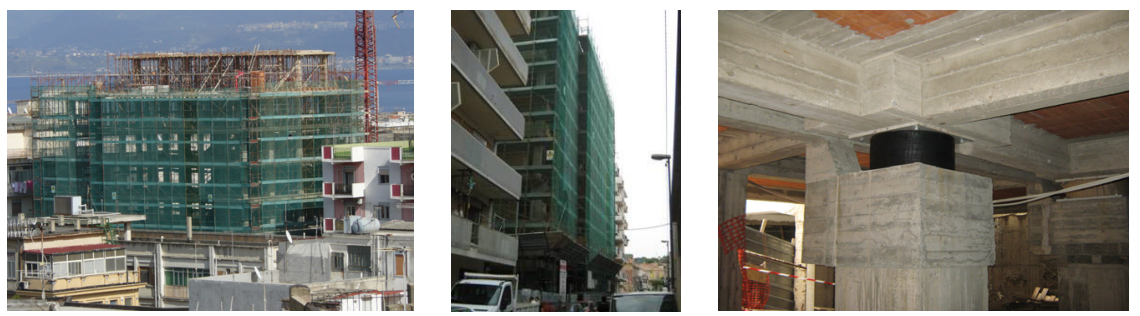

Figure 4: A new 8-storey dwelling building being erected in Messina, in seismic zone 1 (June 2010), the tallest isolated Italian building (its safety will be certified by A. Martelli), and one of the LRBs forming its SI system together with SDs. 

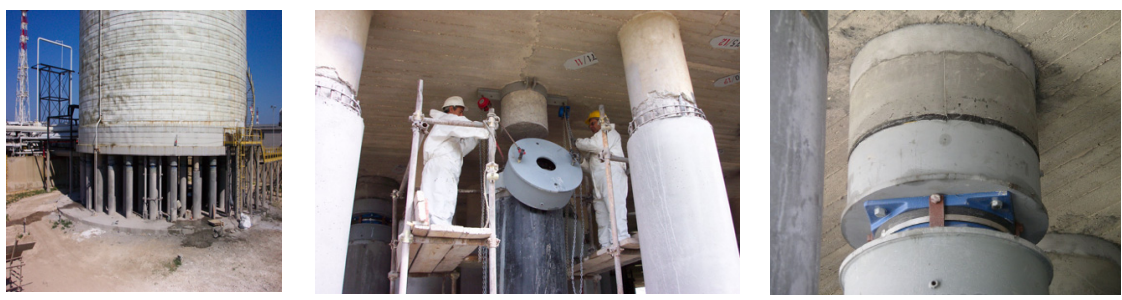

Figure 5: One of the three tanks of the company Polimeri Europa of the Italian ENI Group located in Priolo Gargallo (Augusta, Syracuse, seismic zone $2 *$, which were seismically retrofitted using U.S. FPS devices in the years 2005-2008 and one of the isolators during and after its installation [4] (this is the only application of SI to chemical plants and components so far existing in Italy; prior to the 2009 Abruzzo quake, it was also the only Italian application of CSSs).

The recent applications of SI include 184 pre-fabricated houses erected in L'Aquila, each on a large isolated large r.c. slab (fig. 6), to provisionally host 17,000 homeless residents (at least in the first years). These have been isolated using Italian CSS devices (fig. 6), but the use of the traditional HDRBs or LRBs, in conjunction with some SDs, is also going on, for both new constructions and retrofits (figs. 7-9). In particular, the new Francesco Jovine, protected by a SI system designed with the collaboration of ENEA and formed by 600 and 700 mm diameter HDRBs (61) and SDs (13), which has been the first Italian isolated school (certified as safe by the first author of this paper in September 2009) [3, 4], has been followed by several further projects of this kind (see, for instance, figs. 3 and 7): seismic protection of schools by means of SI, besides that of hospitals and other strategic structures, is now a "priority 1" objective in Italy.
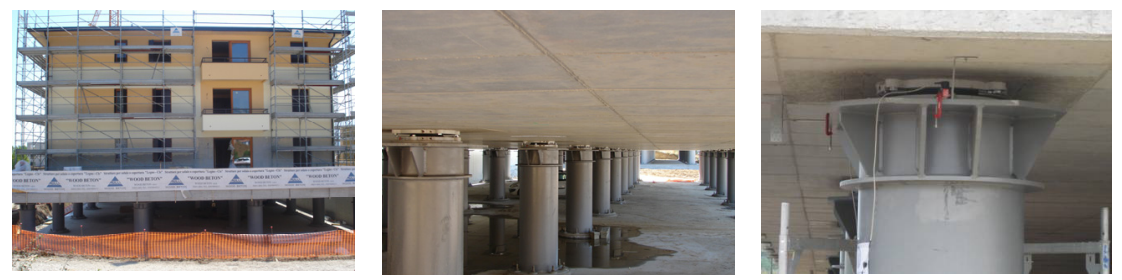

Figure 6: One of the 184 pre-fabricated houses (wood, or r.c., or steel structure) erected in l'Aquila for homeless residents after the 2009 Abruzzo earthquake and some of the 40 CSS devices, manufactured in Italy, installed at the top of columns to isolate its supporting slab (the lower floor is used as garage). 

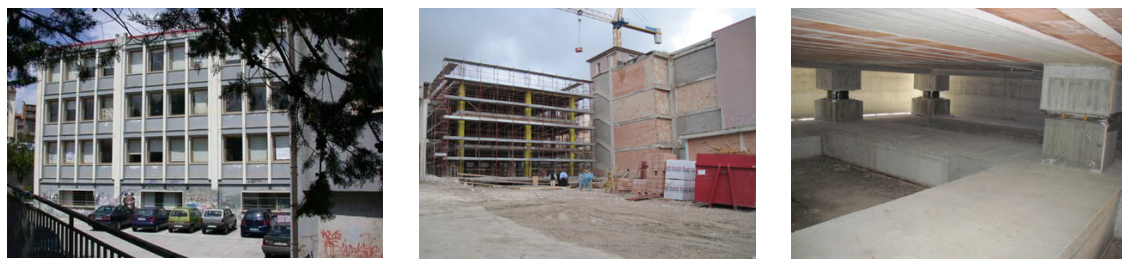

Figure 7: $\quad$ The Romita High School for scientific studies (1,300 students) in Campobasso (seismic zone 2) prior to the demolition of its blocks "A" and "B" (left); reconstruction of block "B" in progress in October 2010 (at the centre); two HDRBs and one SD in its underground technical floor (right).
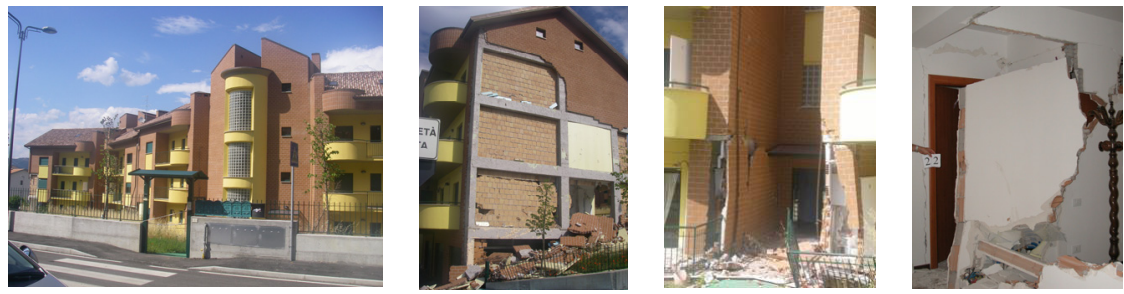

Figure 8: The dwelling building of Via Borgo dei Tigli 6-8-10 in L'Aquila (Pianola area), just completed before the 2009 Abruzzo earthquake (left) and damage caused to the building by this event. Its retrofit by means of HDRBs and SDs has been planned, with safety certification of A. Martelli.
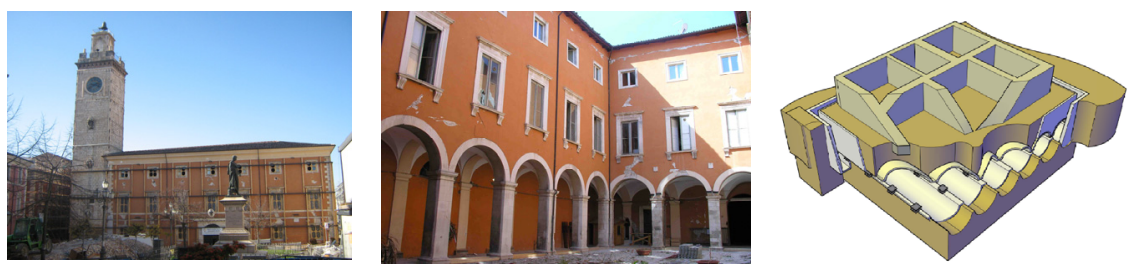

Figure 9: The monumental building Palazzo Margherita in L'Aquila put in safe conditions after of the damages suffered during the 2009 Abruzzo earthquake (left and at the centre); this and further monumental buildings in L'Aquila (including the renowned De Amicis school) may be retrofitted by sub-founding them and inserting a SI system in the sub-foundations, in order to respect the severe conservation requirements applicable in Italy to cultural heritage (among the sub-foundation techniques, that shown on the right, patented by ENEA and the Polytechnic of Torino in 2010, should be used [4]). 
The previous blocks " $\mathrm{A}$ " and "B" of the school had been found to be very unsafe by investigations on the quality of construction materials carried out (with the cooperation of ENEA) after the 2002 Molise and Puglia earthquake [1, 3, 4].

At last, they were demolished in 2010, due to violent polemics on the safety of the school which took place in Campobasso after the 2009 Abruzzo earthquake.

Block "A" should also be reconstructed, as soon as funds become available.

Retrofit with SI at the top of the first floor has been recommended for block "C", which was not demolished because it was found to be characterized by somewhat better construction materials.

Safety of at least block "B" will be certified by A. Martelli.

Moreover, the use of the AS systems is going on for bridges and viaducts (those with such systems were already at least 250 in 2009 [5, 7]) and cultural heritage (fig. 9) [3, 4]: new retrofit techniques using SI, applicable to monumental buildings, will also be applied for reconstructing L'Aquila (fig. 9).

\section{Application in other countries}

For the overall number of applications of the AS systems, Italy is followed by South Korea, Taiwan, Armenia, New Zealand, France, Mexico, Canada, Chile and other countries [3, 4, 7]: many of them make use of Italian AS devices (e.g. Turkey, Greece, Portugal, Spain) and some have also been designed by Italians (Cyprus, Romania). In New Zealand, one of the motherlands of AS devices (in particular of those based on the use of lead) and third in the world for the number of applications of such devices per inhabitants, the isolated structures had an excellent behaviour in both the 2010 Canterbury earthquake, of $\mathrm{M}=7.1$, and the 2011 Christchurch event, of $M=6.3$ (fig. 10) [4, 12]. Similarly, the isolated structures in Santiago had an excellent behaviour in Chile too, during the 2010 Maule earthquake, of $\mathrm{M}=8.8$ (fig. 10) [4].
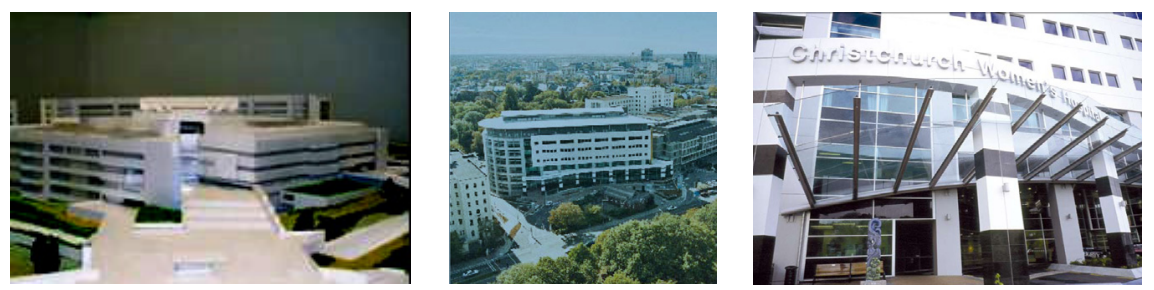

Figure 10: The isolated Nuevo Hospital Militar La Reina in Santiago (Chile), which survived undamaged the Maule earthquake of February 27, 2010 (left), and the isolated Christchurch Woman's Hospital (New Zealand), which had the same behaviour during the event of Canterbury on September 3, 2010 and that of Christchurch on February 21, 2011 (at the centre and right). 


\section{Conclusions and remarks on the correct use of anti-seismic systems}

The large effects of earthquake lessons and seismic design code features on the extent of the use of the AS systems in the various countries shall be stressed [2, $3,4]$. With regards to the code features, in countries like Japan, the USA and Chile SI is considered as a safety measure additional to the conventional design; consequently, the use of SI obviously always introduces additional construction costs. In spite of this, this technique is being widely adopted by the Japanese, due to their high level of perception of the seismic risk and because violent quakes are very frequent in their country. The aforesaid level of perception is much lower elsewhere: this is the reason why, to limit or even balance the additional construction costs entailed by the use of SI (and, thus, promote a significant application of such a technique), the seismic codes of other countries (Italy, China, Armenia, etc.) allow for some lowering of the seismic forces acting on the superstructure and (consequently) foundations when SI is used. Thus, in these countries, a real safety will be ensured to the isolated structures if and only if great care is paid to: (1) the selection of the SI devices (taking into account the amplitude of vertical and low frequency vibrations), their qualification, production quality, installation, protection, maintenance and verification that their design features remain unchanged during the entire structure life; (2) some further construction details (structural gaps, their protections, interface elements - e.g. gas and other safety-related pipes, cables, stairs and lifts, etc.). Otherwise, the isolators, instead of largely enhancing the seismic protection, will make the structure less earthquake resistant than a conventionally founded one and, thus, will expose both human life and the entire SI technology to great risks.

Finally, $[2,13]$, a common key requirement for the optimal performance of all the AS systems and devices (but especially of the isolators) is the realistic and reliable definition of seismic input, which cannot rely upon the oversimplified routine probabilistic methods, mainly when dealing with displacements definition (on which the design of isolated structures is based): thus, the ongoing rapid extension of the use of the AS systems and devices requires a considerable improvement of the Probabilistic Seismic Hazard Assessment (PSHA) approach, which is now in use in several countries (including Italy). Such a change is very urgent now and can be achieved by complementing PSHA through the development and application of deterministic models (e.g. the Neodeterministic Seismic Hazard Assessment, NDSHA) [4, 13]. This particularly applies to China, Italy, New Zealand and Japan, to ensure safe reconstruction after the quakes of Wenchuan (2008), Abruzzo (2009), Canterbury and Christchurch (2010 and 2011) and Tohuku (2011), because SI is widely used in the concerned areas.

All the aforesaid items are being discussed (April 2011) by the Commission on Environment, Territory and Public Works of the Italian Chamber of Deputies, to recommend modifications of the seismic design code to the government [4]). 


\section{References}

[1] Dolce, M., Martelli, A. \& Panza, G., Moderni Metodi di Protezione dagli Effetti dei Terremoti, ed. A. Martelli, $21^{\mathrm{mo}}$ Secolo: Milan, 2006 (in Italian).

[2] Martelli, A., On the need for a reliable seismic input assessment for optimized design and retrofit of seismically isolated civil and industrial structures, equipment and cultural heritage. Pure and Applied Geophysics, DOI 10.1007/s00024-010-0120-2, 2010.

[3] Martelli, A. \& Forni, M., Seismic isolation and other anti-seismic systems: recent applications in Italy and worldwide. Seismic Isolation And Protection Systems (SIAPS), Mathematical Sciences Publishers (MSP): Berkeley, DOI 10.2140/siaps.2010.1.75, 1(1), p. 75-123, 2010.

[4] Martelli, A. \& Forni, M., Recent worldwide application of seismic isolation and energy dissipation and conditions for their correct use. Proc. on $C D$ ROM of the Structural Engineering World Congress, Cernobbio, 2011.

[5] Martelli, A., Sannino, U., Parducci A. \&. Braga, F., Moderni Sistemi e Tecnologie Antisismici. Una Guida per il Progettista, $21^{\mathrm{mo}}$ Secolo: Milan, 2008 (in Italian).

[6] Sannino, U., Sandi, H., Martelli A. \& Vlad, I., Modern Systems for Mitigation of Seismic Action, AGIR Publishing House: Bucharest, 2009.

[7] Martelli, A., Progress of the application of passive anti-seismic systems. Earthquake Resistant Engineering Structures VII, eds. M. Phocas, C.A. Brebbia \& P. Komodromos, Wit Press: Southampton, pp. 281-293, 2009.

[8] Kani, N., Recent Trends of Seismically Isolated Structures in Japan, Japan Society for Seismic Isolation (JSSI), Tokyo, Japan, 2011.

[9] V.G. Kossobokov \& A. Nekrasova, Global Seismic Hazard Assessment Program maps are misleading. Proc. of the AGU Fall Meeting 2010, 2010.

[10] Kani, N. Personal communications, April 2011, Director, JSSI, Japan.

[11] Kawashima, K. Personal communication, April 2011, Professor, Department of Civil Engineering, Tokyo Institute of Technology, Japan.

[12] Whittaker, D. Personal communications, September 2010 and April 2011, Technical Director, Beca, Singapore.

[13] Panza, G., Irikura, K., Kouteva, M., Peresan, A., Wang, Z. \& Saragoni, R., (eds.). Advanced seismic hazard assessment, Pageoph Topical Volume, ISBN 978-3-0348-0039-6 and ISBN: 978-3-0348-0091-4, 2011. 